\title{
The effects of forest fire on the nesting success of the Red-knobbed Hornbill Aceros cassidix
}

\author{
ALEXIS J. CAHILL and JONATHAN S. WALKER
}

\begin{abstract}
Summary
We assessed the impact of forest fire on the nesting success of the endemic Red-knobbed Hornbill Aceros cassidix in north Sulawesi, Indonesia. Pre- and post-fire breeding activity was monitored at 60 nest trees. Low rainfall and possible reductions in fruit abundance did not appear to have an effect on initial nest uptake or on subsequent chick production at non-burnt nests, which were comparable to previous years. However, there was an adverse effect on productivity at nests that directly experienced fire and the accompanying heat and smoke in the vicinity, resulting in a post-fire nest success $(62 \%)$ that was significantly lower than in previous years $(78.6-80 \%)$. Population recruitment dropped by an estimated $47 \%$ to 0.17 fledglings/breeding pair. Our data suggest that, given the reproductive profile of this species and the ability of fire to reinforce its own negative effects on forest habitats, Red-knobbed Hornbill populations may be vulnerable to the potential effects of repeated fires.
\end{abstract}

\section{Introduction}

In 1997 exceptionally intense and widespread fires caused extensive damage to the tropical forests of Indonesia. Contrary to its better-known role in South America, the periodic climatic phenomenon of El Niño induced an unusually severe and extended dry season across the Indonesian archipelago. Early estimates indicated that up to five million hectares of land were burnt (Schweithelm 1998). The combination of drought conditions and detrimental land-use practices enables fires to spread through tropical forests previously believed to be fireresistant (Ginsberg 1998). The few post-fire surveys undertaken in Indonesian tropical forest have shown that fire damage is positively correlated with the level of prior human disturbance (Schindele et al. 1989), and previous history of burning (Kinnaird and O'Brien 1998, Yeager 1997). Although the ecological effects of catastrophic fires are poorly understood, studies of bird and mammal populations have pointed to survival being primarily dependent on both a species's mobility and its ability to adapt to post-fire changes in the availability of food resources (Doi 1988, Kinnaird and O’Brien 1998, Mayer 1989, Wirawan 1985).

Hornbills are among the more highly mobile species of Indonesia's forests and may be capable of escaping the immediate threats of fire. However, their breeding habits (including a prolonged nesting period) and diet may combine to promote their vulnerability. All true hornbills are cavity nesters and females seal 
themselves into the nest, often undergoing a simultaneous moult of their flight feathers (Kemp 1995), which leaves female birds defenceless against passing fires for a large portion of the year. In addition, Asian hornbills are generally highly frugivorous; a loss of fruit trees or changes in phenological patterns due to drought and heat stress may have adverse effects (M. Leighton 1983 unpublished report), especially during the breeding season when males cannot range so widely and provisioning demands are high.

An ongoing seven-year study into the ecology of the Red-knobbed Hornbill Aceros cassidix at the Tangkoko-Dua Saudara Nature Reserve, Sulawesi (hereinafter Tangkoko) provided us with the base-line ecological data needed to carry out a comparative study on the effects of fires on the Red-knobbed Hornbill during the 1997-1998 breeding season. Tangkoko is a 8,900 ha reserve bordered by ocean and agricultural lands which are subject to habitat modification, adding to the reserve's isolation from nearby forest blocks. Such isolation increases the vulnerability of animal populations in the face of catastrophic events such as forest fires (Soulé 1987). Fires entered Tangkoko in August 1997 from adjacent agricultural land and were extinguished by rains in October 1997. An estimated $55 \%$ of the forest area was damaged (R. Lee, 1998 in litt.).

The Red-knobbed Hornbill occurs at extremely high population densities at Tangkoko (average, 51 hornbills $/ \mathrm{km}^{2}$ ) (Kinnaird et al. 1996) and nesting densities are as high as 10.4 pairs $/ \mathrm{km}^{2}$ (Kinnaird and O'Brien 1999). Several aspects of Red-knobbed Hornbill ecology and behaviour have already been investigated, including studies of breeding biology (Kinnaird and O'Brien 1993, Kinnaird and O'Brien 1999), feeding ecology (Suryadi et al. 1994), movement patterns (M. F. Kinnaird et al. 1996 unpublished report) and population abundance and distribution (M. F. Kinnaird et al. 1996).

In this paper, we examine the effects of forest fires on the breeding success of the Red-knobbed Hornbill. Specifically, we investigate the effects of smoke and fire at nest sites on Red-knobbed Hornbill and nest tree mortality. These data provide insight into the vulnerability of this species to large-scale forest fires and help predict the consequences of future fires on this insular population.

\section{Study area and methods}

Data were collected in the Tangkoko Nature Reserve $\left(1^{\circ} 34^{\prime} \mathrm{N}, 125^{\circ} 14^{\prime} \mathrm{E}\right)$, situated on the northern arm of Sulawesi. The reserve is of high conservation importance due to both the number of forest types it protects (lowland rainforest, submontane rainforest, elfin cloud-forest, beach-forest and casuarina forest) and high numbers of endemic species. Our study was conducted in a $5 \mathrm{~km}^{2}$ research site on the northern slope of the Tangkoko volcano. The site includes primary forest, naturally disturbed forest and previously burnt forest (see Kinnaird and O'Brien 1995, for a more detailed description of the study area). The study area had previously experienced fire damage in 1992 with an estimated 129 ha (25.8\%) being classified as severely damaged with both the substage and canopy affected. Annual rainfall for Tangkoko averages $1790 \mathrm{~mm}$ but rainfall for 1997 was 924 $\mathrm{mm}$, with only $51 \mathrm{~mm}$ falling between June and October.

We began monitoring 60 previously used nest trees at the beginning of the Red-knobbed Hornbill breeding season in June 1997. A nest was classified as 
Table 1. Summary of nest activity for burnt and non-burnt habitat

\begin{tabular}{lccr}
\hline Status of nest trees & $\begin{array}{c}\text { Pre-burn } \\
\text { active nests }\end{array}$ & Active nests & Non-active nests \\
\cline { 3 - 4 } & 23 & $11(48 \%)$ & $12(52 \%)$ \\
Burnt & 19 & $15(78 \%)$ & $4(22 \%)$ \\
Non-burnt & 42 & $26(62 \%)$ & $16(38 \%)$ \\
Total & & & \\
\hline
\end{tabular}

active if we detected the following indicators: vocalizations from inside the nest; male observed delivering food to the nest; an intact nest seal or the distinctive sound of the nest being sealed by the female; fresh faecal material below the nest. Fires entered the reserve in August, after females had incarcerated themselves in their nests, and burnt for two months into October. We conducted a post-fire check of the nests in November to assess activity status and nest tree damage. During the post-fire assessment, breeding attempts were classified as unsuccessful if previously active nests were subsequently found empty. We also noted whether the nest tree and habitat within a circular plot of $15 \mathrm{~m}$ radiating from the base of the tree had been damaged by fire. Damage was characterized as canopy, subcanopy or substage.

We used data from Kinnaird and O'Brien (1993 and 1999) for comparisons of reproductive success and information on previous forest fires. Additional data, on occupancy and nest heights, were available for a subset of nests which we had surveyed in 1996 (A.J.C. pers. obs.).

\section{Results}

Of 61 nest trees recorded in use in 1996, 11 fell between the 1996 and 1997 breeding seasons. This was probably due to a combination of stress from drought conditions and strong seasonal winds (pers. obs.). A further three trees were rendered unusable because of fire damage. This was a significantly higher proportion of available nest trees lost $(23 \%)$ than the average of $2.2 \%$ (1.33/year) for previous years (1993-1996), ( $z$-test: $z=11.93, P<0.001$ ).

All female hornbills had entered nests by 6 August $1997(n=42)$. Although this was a year of severe drought, nest uptake $(70.0 \% ; 42 / 60)$ and nest density (8.4 pairs $/ \mathrm{kM}^{2}$ ) were comparable to previous years (1993-1996, 67.1-80.3\% and 8.2-10.4 pairs $/ \mathrm{km}^{2}$, respectively).

Hatching, fledging and overall nesting success were high and fairly constant between 1993 and 1995 (88.5-90.7\%; 88.0-89.9\%; and 78.6-80\%, respectively); but the 1997 post-fire nest success was only $62 \%(26 / 42)$, a significantly lower proportion than in preceding years $(z=2.535, P=0.0112)$. Two dead chicks, with underdeveloped feathers, and a charred female found outside three nest trees provided evidence of attempts to flee nests prematurely.

Of the 42 nests known to be active before the onset of fires, $23(55 \%)$ were in burn areas. Comparison of burn and non-burn sites showed that nests not subjected to fire were significantly more likely to be successful than nests which experienced fire $(z=3.617, P=0.0003$; see Table 1$)$. A comparison of the 1997 post-fire success rate for nests that did not experience fire, with hatchling success in previous years, showed no significant difference $(z=0.853, P=0.3937)$. 
Kinnaird and O'Brien (1999) estimated that in a normal year the Tangkoko Red-knobbed Hornbill population averaged a recruitment rate of 0.32 fledglings / female per year. In 1997, based on nesting densities of 9.0 females $/ \mathrm{km}^{2}$, nesting success of $50 \%$ and a population density of $51 \mathrm{birds} / \mathrm{km}^{2}$, the population increased by only 0.17 fledglings/female. This amounts to a drop in population recruitment of $47 \%$.

Contrary to expectations we found no evidence to suggest that nests situated in already degraded forest were more likely to burn than those in undisturbed habitats. Conversely, nests in undisturbed habitat $(n=11)$ suffered significantly more fire damage than those in disturbed or previously burnt habitats $(z=2.9946$, $P=0.0027)$.

\section{Discussion}

Red-knobbed Hornbills experienced a marked decrease in nest success as an immediate result of the 1997 fires. A supposed reduction in food abundance, caused by low rainfall or a loss of fruit trees in the fire, had no apparent affect on chick production. The overriding factor contributing to the decrease in productivity was the presence of fire and associated heat and smoke at or close to the nest tree, presumably resulting in direct mortality of the female and chick or nest abandonment by the female.

M. Leighton (1983 unpublished report) attributed an absence of hornbills immediately after forest fires to the mortality of a large percentage of fruit trees, upon which they depended for food. Fruit is also the primary component of the Red-knobbed Hornbill diet, making up over $80 \%$ of food items delivered to the nest by the male (Kinnaird and O'Brien 1999). Although approximately 55\% of the reserve was burnt, a comparison of nesting success between burn sites, nonburn sites and previous seasons indicated that only nests directly affected by the fire were subject to an increase in nest failure or abandonment. However, as Red-knobbed Hornbills are thought to time chick fledging with peaks in fruit abundance (Kinnaird and O'Brien 1999) any disruption to fruiting patterns may have longer-term consequences through effects on juvenile development and survival.

The increased fire damage suffered by nests in undisturbed forest over those in lightly disturbed or previously burnt forest could have resulted from differences in forest structure and fuel loads between these habitats. We noted that during the prolonged dry spell, drought stress caused many trees to drop their leaves resulting in a build-up of leaf litter especially in the high biomass, undisturbed forest. Increased solar radiation to the forest floor would have contributed to the drying out of the lower strata. We propose that in these conditions, the combination of abundant leaf litter and the better-formed subcanopy found in undisturbed forest may have carried the fire to hornbill nests more effectively.

Ultimately, the reduction in chick production for 1997 probably represents only a temporary fluctuation in the demography of this population. Perhaps of more significance is the loss of breeding females and further degradation of Redknobbed Hornbill habitat through a loss of nest trees and possibly fruiting trees. It is very likely that severe forest fires will reoccur in Tangkoko at the next El Niño event. As fire is able positively to reinforce its own negative effects on 
forest habitats (Ginsberg 1998), there is the potential in the future for a long-term adverse effect on population stability.

Fire is an increasing threat to the biodiversity of Indonesia's flora and fauna; although it has always played a part in the disturbance of Indonesia's forests, the scale and intensity has increased in the past three decades due to human actions. These findings highlight the problematic nature of attempting to conserve species in a small isolated reserve and the need for reliable, long-term ecological data if we are to learn what impacts such catastrophic events have on the ecology and future conservation of the region's wildlife.

\section{Acknowledgements}

Funding for this project was provided through a Research Fellowship Grant awarded by the Wildlife Conservation Society. Dr Margaret Kinnaird and Dr Timothy O'Brien are especially thanked for guidance, encouragement and support throughout the project and for commenting on the manuscript. Dr Martin Jones and Dr Alan Fielding are thanked for providing assistance as our supervisors and Jemmy for helping collect data. We thank Puslitbang Biologi of the Indonesian Institute of Sciences (PB/LIPI) and the Directorate General for Nature Preservation and Forest Protection (PHPA) for their sponsorship in Indonesia. We are also grateful to the following bodies for providing additional financial or material support: Manchester Metropolitan University, The Rhode Island Zoological Society and Chester Zoological Gardens.

\section{References}

Doi, T. (1988) Present status of large mammals in Kutai National Park after a large-scale fire in East Kalimantan. In H. Tagawa and N. Wirawan, eds. A research on the process of earlier recovery of tropical rain forest after a large-scale fire in Kalimantan Timur, Indonesia. Indonesia: Kagoshima University.

Ginsberg, J. R. (1998) Perspectives on wildfire in the humid tropics. Conserv. Biol. 12: 942943.

Kemp, A. (1995) Bird families of the world: the Hornbills, Bucerotiformes. Oxford: Oxford University Press.

Kinnaird, M. F. and O'Brien, T. G. (1993) Preliminary observation on the breeding biology of the endemic Sulawesi Red-knobbed Hornbill Rhyticeros cassidix. Trop. Biodivers. 1: 107-112.

Kinnaird, M. F. and O'Brien, T. G. (1995) Tangkoko-Duasudara Nature Reserve, North Sulawesi, management plan 1996-2000. Bogor, Indonesia: Wildlife Conservation Society.

Kinnaird, M. F. and O'Brien, T. G. (1998) Ecological effects of wildfire on lowland rainforest in Sumatra. Conserv. Biol. 12: 954-956.

Kinnaird, M. F and O'Brien, T. G. (1999) Breeding ecology of the Sulawesi Red-knobbed Hornbill, Aceros cassidix. Ibis 141: 60-69.

Kinnaird, M. F., O'Brien, T. G. and Suryadi, S. (1996) Population fluctuation in Sulawesi Red-knobbed Hornbills: tracking figs in space and time. Auk 113: 431-440.

Mayer, J. H. (1989) Socioeconomic aspects of the forest fire of 1982/83 and the relation of local communities towards forestry and forest management. Samarinda: German Agency for Technical Cooperation (GTZ)/ ITTO (FR report 8).

Schindele, W., Thoma, W. and Panzer, K. (1989) The Kalimantan forest fire of 1982-3 in East 
Kalimantan, I. The fire, the effects, the damage and technical solutions. Jakarta: German Agency for Technical Cooperation (GTZ)/ITTO. (FR report 5).

Schweithelm, J. (1998) The fire this time: an overview of Indonesia's forest fires in 1997/98. Jakarta: WWF Indonesia Programme.

Soulé, M.E. (1987) Viable populations for conservation. Cambridge: Cambridge University Press.

Suryadi, S., Kinnaird, M. F., O’Brien, T. G., Supriatna, J. and Somadikarta, S. (1994) Food preferences of the Sulawesi Red-knobbed Hornbill during the non-breeding season. Trop. Biodivers. 2: 377-383.

Wirawan, N. (1985) Kutai National Park management plan 1985-1990. Jakarta, Indonesia: WWF/IUCN.

Yeager, C.P. (1997) Fire effects on wildlife and ecosystem processes. Jakarta: WWF Indonesia Programme.

ALEXIS J. CAHILL and JONATHAN S. WALKER

Department of Biological Sciences, Manchester Metropolitan University, Chester Street, Manchester Mi 5 GD, U.K. 